Assiut University web-site: $\underline{w w w . a u n} . e d u . e g$

\title{
OCCUERRENCE OF THERMOTOLERANT CAMPYLOBACTERS IN TABLE EGGS
}

\author{
MONA A. EL-ZAMKAN \\ Department of Food Hygiene and Control, Faculty of Veterinary Medicine, South \\ Valley University, Qena 83523, Egypt
}

Received: 31 December 2016; $\quad$ Accepted: 30 January 2017

\begin{abstract}
Thermotolerant Campylobacter spp. particularly $C$. jejuni and $C$. coli are recognized as the leading causes of bacterial foodborne diarrheal disease throughout the developed and developing world for more than century. A total of 500 eggs of Baladi and large scale eggs (250 eggs each) were collected from farmers' houses and markets in Qena Governorate. Samples were divided into pools (each pool contained 5 eggs obtaining 100 pools) and were examined for existence of thermotolerant Campylobacter spp. on their egg shells and in their inner content. The biochemically identified $C$. jejuni and $C$. coli isolates were confirmed using multiplex PCR. Thermotolerant Campylobacter spp. were isolated from 15 and $5 \%$ of egg shell and egg content samples, respectively. Isolates from egg shell samples were distributed as C. jejuni (9\%), C. coli (4\%), C. lari (1\%) and C. upsaliensis (1\%), while isolates from egg content samples were identified as $C$. jejuni (4\%) and C. lari (1\%). Large scale egg samples which are produced by poultry farms lacked thermotolerant Campylobacter spp. Whereas, 30 and $10 \%$ of Baladi egg samples collected from farmers' houses were contaminated with thermotolerant Campylobacter spp. on their egg shell and in their content, respectively. This study focuses on the risk of transmission of thermotolerant Campylobacter spp. through table eggs, especially that produced by farmers' houses (Baladi egg), in Qena.
\end{abstract}

Key words: Thermotolerant Campylobacter spp., Table eggs, C. jejuni, C. coli, mPCR.

\section{INTRODUCTION}

The significance of thermotolerant Campylobacter as a foodborne pathogen of major public health concern is well recognized worldwide due to the high burden of disease caused by this species (EFSA, 2014). Campylobacter is one of the most frequently isolated bacteria from infants with diarrhea in developing countries (Coker et al., 2002). $C$. jejuni and $C$. coli particularly among thermotolerant spp. have become the most common cause of human bacterial gastroenteritis which is the main disorder caused by it (Robyn et al., 2015). C. jejuni and $C$. coli have been implicated in most foodborne cases, $C$. jejuni is responsible for $90 \%$ of the outbreaks, whereas $C$. coli only accounts for $5 \%$ of the outbreaks (EFSA, 2005). The majority of human infections are self-limiting (Wei et al., 2016) but in some cases, it causes other serious immunoreactive complication such as Rieter's and Guillain-Barré syndrome (EFSA, 2011, Adzitey et al., 2012 and Bolton, 2015).

Corresponding author: Dr. MONA A. EL-ZAMKAN

E-mail address: M_zam@vet.svu.edu.eg

Present address: Department of Food Hygiene and Control, Faculty of Veterinary Medicine, South Valley University, Qena 83523, Egypt.
Poultry, specifically broilers and laying hens is the main important reservoir of thermotolerant Campylobacter spp. (EFSA, 2010 and Josefsen et al., 2015). Therefore, chicken meat is the major source of food-borne Campylobacteriosis (Ganan et al., 2012). Despite of accumulation of circumstantial evidences that favor horizontal transmission from the environment as the most probable source of infection by Campylobacter through old litter, untreated drinking water, other farm animals, domestic pets, wildlife species, house flies, insects, equipment and transport vehicles, and farm workers (Sahin et al., 2002). There is increasing evidence suggests that vertical transmission of Campylobacter to the egg may occur through reproductive tract (Maruyama and Katsube, 1990, Jacobs-Reitsma, 1997 and Camarda et al., 2000).

Eggs are recognized as an exceptional nutritive complete product whose technological and flavoring characteristics countenance their use as a multifunctional element in the food industry (Espina et al., 2014). Although the role of the eggs as a vehicle for Campylobacter transmission has been studied, egg wasn't mentioned by EFSA (2015) amongst food related to Campylobacteriosis. There is only some information available about the predominance of thermotolerant Campylobacter spp. 
on the eggshell or in the egg inner content itself. These data can be used for a hazard evaluation concerning potential human foodborne Campylobacteriosis through cross-contamination of ready-to eat food or through ingesting undercooked eggs or food produced with uncooked egg (Messelhäusser et al., 2011). The goal of this study was to detect thermotolerant Campylobacter spp. in the table egg hence evaluating it as a risk for Campylobacter transmission.

\section{MATERIALS AND METHODS}

\section{Samples:}

A total of 500 eggs of Baladi and large scale eggs (250 eggs each) were collected from farmers' houses and markets in Qena Governorate. Samples were transferred to the laboratory without delay to be examined for the presence of thermotolerant Campylobacter spp. Eggs were divided into pools, and each pool contained 5 eggs obtaining 100 pools.

\section{Isolation of Campylobacter spp. from Egg Samples Preparation of the samples}

Egg shells were tested by a surface rinse method (Musgrove et al., 2005). Egg shell rinses were obtained by putting each sample in a sterile bag containing $500 \mathrm{ml}$ of Buffered Peptone water and shaking for about $5 \mathrm{~min}$. Then the eggs were removed and the surface of the eggs was sterilized and aseptically cracked and egg contents were received in a sterile beaker and mixed with a sterile fork.

Isolation of Campylobacter spp. (Adzitey et al., 2012)

Twenty five $\mathrm{ml}$ of each egg rinse solution and egg content sample $(25 \mathrm{ml}$ each) were added to Bolton broth (supplemented with Bolton broth Selective Supplement and Laked Horse Blood, Oxoid) which was then incubated at $42{ }^{\circ} \mathrm{C}$ for $48 \mathrm{~h}$ in an anaerobic jar containing a gas mixture of $10 \% \mathrm{Co}_{2}, 5 \% \mathrm{O}_{2}$ and $85 \% \mathrm{~N}_{2}$ that provided by gas generating kit (Oxoid). The mCCDA agar (Campylobacter blood free selective agar, Oxoid) which was supplemented with CCDA selective supplement, (Oxoid), were then streaked with a loopful of each enrichment broth and subsequently incubated at $42{ }^{\circ} \mathrm{C}$ for $48 \mathrm{~h}$ under microaerobic condition. From 2-3 presumptive Campylobacter colonies were purified on Columbia Blood Agar (containing 7\% defibrinated sheep blood) without supplement. Campylobacter isolates were submitted to Gram stain, oxidase, catalase, inability to grow aerobically at $25{ }^{\circ} \mathrm{C}$, hippurate hydrolysis and resistance to nalidixic acid and cephalothin.

Identification of $C$. jejuni and $C$. coli using Multiplex Polymerase Chain Reaction (mPCR): DNA extraction

DNA extraction from isolates was operated using the QIAamp DNA Mini kit (Qiagen, Germany, GmbH) with remodeling of the manufacturer's recommendations. In brief, $200 \mu$ of the sample suspension was incubated with $10 \mu$ of proteinase $\mathrm{K}$ and $200 \mu \mathrm{l}$ of lysis buffer at $56^{\circ} \mathrm{C}$ for $10 \mathrm{~min}$. Following the incubation, $200 \mu \mathrm{l}$ of $100 \%$ ethanol was added to the lysate. The sample was thereafter washed and centrifuged according to the manufacturer's recommendations. Nucleic acid was eluted with $100 \mu$ of elution buffer afforded with the kit.

\section{Multiplex Polymerase Chain Reaction (mPCR)}

Multiplex PCR was used to confirm $C$. jejuni according to the primer sequence 5'ACTTCTTTATTGCTTGCTGC3' and 5'GCCACAACAAGTAAAGAAGC3', while the primer 5'GTAAAACCAAAGCTTATCGTG3' and 5'TCCAGCAATGTGTGCAATG3' used to confirm C. coli isolates (Wang et al., 2002). Primers used were supplied from Metabion (Germany).

\section{PCR amplification and analysis of the PCR Products}

The PCR mixture reaction $(50 \mu \mathrm{l})$ consisted of $25 \mu \mathrm{l}$ of Emerald Amp Max PCR Master Mix (Takara, Japan), $1 \mu \mathrm{l}$ of each primer of $20 \mathrm{pmol}$ concentrations, $9 \mu \mathrm{l}$ of water, and $12 \mu \mathrm{l}$ of DNA template. Amplification of DNA was accomplished with 35 cycles of the following: primary denaturation at $94^{\circ} \mathrm{C}$ for $10 \mathrm{~min}$, annealing at $55^{\circ} \mathrm{C}$ for $30 \mathrm{~s}$ and extension at $72{ }^{\circ} \mathrm{C}$ for $30 \mathrm{~s}$ with a final extension time of $72^{\circ} \mathrm{C}$ for $7 \mathrm{~min}$ in an Applied biosystem 2720 Thermal Cycler. Then separation of PCR products was performed by electrophoresis on $1.5 \%$ agarose gel (Applichem, Germany, GmbH) in 1x TBE buffer at room temperature using gradients of $5 \mathrm{~V} / \mathrm{cm}$. For gel analysis, $30 \mu \mathrm{l}$ of the products were loaded in each gel slot. A 100 bp DNA Ladder (Qiagen, Germany, $\mathrm{GmbH}$ ) was used to determine the fragment sizes. The gel was photographed by a gel documentation system (Alpha Innotech, Biometra) and the data was analyzed through computer software.

\section{RESULTS}

In the present study thermotolerant Campylobacter spp. could be isolated from $15 \%$ of the total egg shell samples and $5 \%$ of the total egg content samples (Table 1). C. jejuni, C. coli, C. lari and C. upsaliensis identified in 9, 4, 1 and $1 \%$ of the egg shell samples, respectively and $4,0,1$ and $0 \%$ of the egg content samples, respectively (Table 2).

From data illustrated in Table 2 it is obvious that neither the egg shell nor the egg content of poultry farms egg samples harbored thermotolerant Campylobacter spp., while Baladi egg samples obtained from farmers' houses were found to be contaminated with thermotolerant Campylobacter spp. in percentage of 30 and $10 \%$ for the egg shell 
and inner egg content, respectively. Campylobacter spp. recovered from Baladi egg samples was distributed as follow: C. jejuni isolated from 18 and $8 \%$ of egg shell and egg content, respectively (photo1), C. Lari detected in $2 \%$ of each egg shell and egg content samples, while $C$. coli and $C$. upsaliensis isolated from egg shell samples only in a percent of 8 and 2\%, respectively (Table 2 and photo 1).

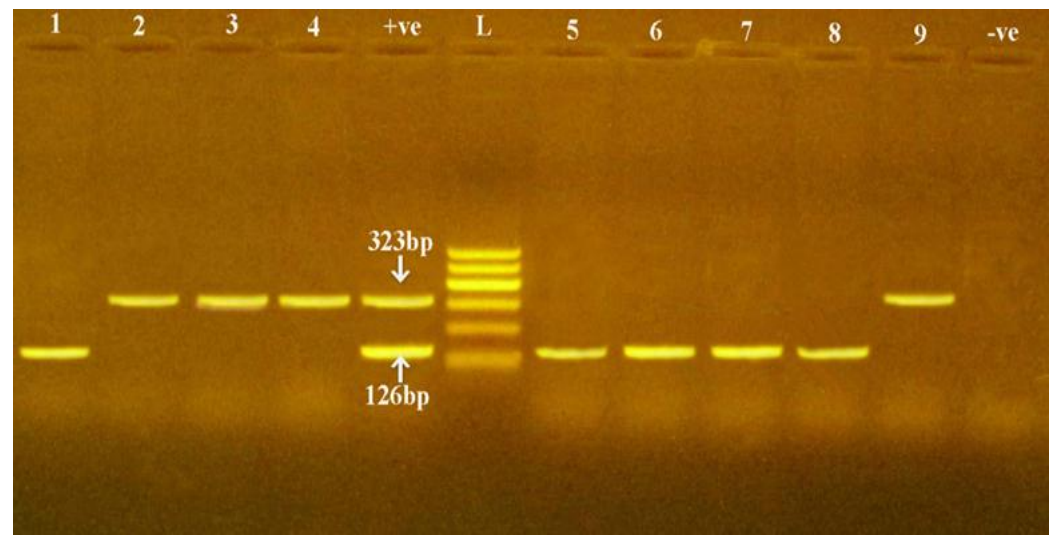

Photo-1: Multiplex-PCR of $C$. jejuni and C. coli strains isolated from egg sgell and egg content samples. Lane (+ve): positive control. Lane (-ve): negative control. Lane (L): 100 bp ladder as DNA marker. Lanes 1, 5, 6, 7 and 8 are positive for $C$. jejuni. Lanes 2, 3, 4 and 9 are positive for $C$. coli.

Table 1: Incidence of thermotolerant Campylobacter spp. in the examined egg pools.

\begin{tabular}{cccccc}
\hline \multirow{2}{*}{ Egg Samples } & \multirow{2}{*}{ No. of Samples } & \multicolumn{2}{c}{ Egg Shell } & \multicolumn{2}{c}{ Egg Content } \\
\cline { 3 - 7 } & & No. & $\%$ & No. & $\%$ \\
\hline Poultry Farms & 50 & 0 & 0 & 0 & 0 \\
\hline Farmers' houses (Baladi) & 50 & 15 & 30 & 5 & 10 \\
\hline Total & 100 & 15 & 15 & 5 & 5 \\
\hline
\end{tabular}

Table 2: Distribution of thermotolerant Campylobacter spp. in egg shells and content

\begin{tabular}{|c|c|c|c|c|c|c|c|c|c|c|c|}
\hline \multirow[b]{2}{*}{ Source } & \multirow[b]{2}{*}{$\begin{array}{c}\text { No. of } \\
\text { samples }\end{array}$} & \multicolumn{5}{|c|}{$\begin{array}{l}\text { Egg shell } \\
\text { No. }(\%) \\
\end{array}$} & \multicolumn{5}{|c|}{$\begin{array}{l}\text { Egg content } \\
\text { No. }(\%) \\
\end{array}$} \\
\hline & & $\begin{array}{c}C . \\
\text { jejuni }\end{array}$ & $\begin{array}{l}\text { C. } \\
\text { coli }\end{array}$ & $\begin{array}{c}C . \\
\text { lari }\end{array}$ & $\begin{array}{c}C . \\
\text { upsaliensis }\end{array}$ & $\begin{array}{c}\text { Total } \\
\text { No./50 (\%) }\end{array}$ & $\begin{array}{c}C . \\
\text { jejuni }\end{array}$ & $\begin{array}{c}C . \\
\text { coli }\end{array}$ & $\begin{array}{c}C . \\
\text { lari }\end{array}$ & $\begin{array}{c}C . \\
\text { upsaliensis }\end{array}$ & $\begin{array}{c}\text { Total } \\
\text { No./50 } \\
(\%)\end{array}$ \\
\hline $\begin{array}{c}\text { Poultry } \\
\text { Farm }\end{array}$ & 50 & 0 & 0 & 0 & 0 & 0 & 0 & 0 & 0 & 0 & 0 \\
\hline $\begin{array}{c}\text { Farmers' } \\
\text { houses } \\
\text { (Baladi) }\end{array}$ & 50 & $9(18)$ & $4(8)$ & $1(2)$ & $1(2)$ & $15(30)$ & $4(8)$ & 0 & $1(2)$ & 0 & $5(10)$ \\
\hline Total & 100 & $9(9)$ & $4(4)$ & $1(1)$ & $1(1)$ & $15(15)$ & $4(4)$ & 0 & $1(1)$ & 0 & $5(5)$ \\
\hline
\end{tabular}

\section{DISCUSSION}

Thermotolerant Campylobacter spp. could not be isolated from commercial eggs produced by large poultry farms giving an image of the hygienic measures applied in the farm and its role in the freedom of eggs from Campylobacter contamination as eggs are frequently collected and separated from hens plus there is no potential transport of Campylobacter from wild birds or other animals to the flock and subsequently their eggs. This result is identical with Moyle et al. (2016) who didn't isolate
Campylobacter spp. from egg shell wash or internal contents of egg samples collected from 2 farms. While, Adesiyun et al. (2005) found 2 out of 46 samples were positive for Campylobacter spp., both isolates belonged to the contents of eggs.

On the other hand, in this study all Campylobacter isolates obtained from egg samples that collected from farmers' houses (Baladi egg). In farmers' houses birds are subjected to be in contact with wild birds that is considered natural reservoirs of Campylobacter spp. and are frequently mentioned as 
possible vectors for transmission to poultry (Waldenström et al., 2002). Also eggs are laid in unhygienic environment includes damp places contaminated with feces, old liter, and untreated drinking water.

It is very obvious from results recorded in this study that the egg shell was more subjected to contamination with thermotolerant Campylobacter spp. than the egg content as 15 of eggshell versus $5 \%$ of egg content collected from both poultry farms and farmers' houses were contaminated. The existence of the environmental conditions in which eggs are laid as mentioned before facing the fact that Campylobacter must compete forcefully with different microflora that present at high numbers in feces to penetrate through the eggshell, considering its week competitive nature, in addition to the adverse impact of high $\mathrm{pH}$ and the presence of bactericidal compounds, like lysozyme and conalbumin, in the albumen on it if penetration happened (Sahin et al., 2003) resulted in that diversity in the incidence of the egg shell contamination and egg content contamination.

Regarding the total prevalence of Campylobacter spp., it was noticed that Jonaidi-Jafari et al. (2016) recorded lower incidence of egg shell samples contaminated by Campylobacter spp. (7\%) which distributed as $C$. jejuni $(5 \%)$ and $C$. coli $(2 \%)$. In the same time, they registered weakly higher prevalence of Campylobacter spp. (6\%) and C. jejuni (5\%) in the egg content. Unlike this study $C$. coli $(1 \%)$ could be isolated by them from the internal content of the egg. Also lower incidence recorded by Messelhäusser et al.(2011) who detected Campylobacter spp. in $4.1 \%$ of the egg shell samples. Eight and 3 isolates were confirmed as $C$. coli and $C$.jejuni, respectively.

Detection of Campylobacter spp. in the internal egg content of farmers' houses could be explained as follow: in farmers' houses the eggs remain in contact with hens, fecal materials and damp environment until they are collected. During this period there is a chance for the microbe entrance through the egg shell's pores, which have an average diameter of 11 $\mu \mathrm{m}$ to $12 \mu \mathrm{m}$ (Fonseca et al., 2014) due to its motility and its size which is smaller than the diameter of the pores (Vandamme et al., 1992), thus rendering the consumption of the contaminated egg a potential risk to human health.

No Campylobacter was isolated from the shell surface of two Baladi egg samples which had the organism in their internal content. This may be contributed to 2 probabilities; the first one is the death of Campylobacter on the shell due to its sensitivity to the dry conditions and atmospheric oxygen (Park, 2002). Shane et al. (1986) affirmed that when they reported that the viability of $C$. jejuni on the fecally contaminated shell egg was retained for only $16 \mathrm{~h}$ due to desiccation of the fecal suspension. While, the second one is contamination of the egg content with Campylobacter was caused by systemic infection of the hen's reproductive tract. $C$. jejuni has been isolated from the ovaries and oviducts of healthy laying chicken hens by Jacobs-Reitsma (1997); Camarda et al. (2000) and from matured yellow follicles and lower oviduct of experimentally infected laying quails by Maruyama and Katsube (1990) unveiling the role of infected reproductive organs in the contamination of eggs.

There is a fake conviction that eggs produced by farmers' houses (Baladi) are further nutritious and microbiologically safe however the findings of this investigation proved the microbiological hazard associated with it. Faraway from laboratory conditions, in the ordinary kitchen throughout cooking, it is approximately impossible to crack eggs aseptically. Therefore, polluted eggshells constantly create a threat of cross-contamination of the egg content with pathogens and of subsequent initiation of food-borne infections when producing ready-to eat food with uncooked or undercooked egg content. The other prospect is cross-contamination from the eggshell to other ready-to-eat meals or products which do not include the egg content itself. During the cooking or production process, the threat of crosscontamination can be excluded only through application of special and very strict hygienic measures. Accordingly, contamination of the eggshell has to be of much more importance for a human foodborne infection than the presumed very low contamination rate and short viability of thermotolerant Campylobacter spp. that reported by many authors like Doyle (1984), Neill et al. (1985), Clark and Bueschkens (1986), Shane et al. (1986) and Maruyama et al. (1995), in particular with the fast movement of the egg in the market, thus rendering egg a hazard for Campylobacteriosis in humans.

Finally, safe handling and processing techniques should not only be implemented into food safety and quality control systems of the food business operators, but also be communicated to the consumers. Egg washing with sanitizers is a common procedure to minimize shell contamination, however; this process is noticeably variable as it isn't always obligatory to wash eggs. Regulations prohibiting the sale of dirty and/or cracked eggs should be developed and activated.

\section{CONCLUSION}

Table eggs sold in Qena represent a risk for transmission of thermotolerant Campylobacter spp. in which $C$. jejuni followed by $C$. coli are superior species. All contaminated samples belonged to Baladi egg samples accentuating that eggs obtained from large poultry farms are safer due to the good hygienic conditions applied in these farms. Primary 
disinfection of the egg surface with disinfectant, separation of dirty eggs from clean one and application of safe handling procedures can reduce the hazard of human Campylobacteriosis.

\section{ACKNOWLEDGMENTS}

I am thankful to all staff members of the Food Hygiene and Control Department, Faculty of Veterinary Medicine, South Valley University, Qena, Egypt for their technical help.

\section{REFERENCES}

Adesiyun, A.; Offiah, N.; Seepersadsingh, N.; Rodrigo, S.; Lashley, V.; Musai, L. and Georges, K. (2005): Microbial health risk posed by table eggs in Trinidad. Epidemiol. Infect., 133:1049-1056.

Adzitey, F.; Rusul, G.; Huda, N.; Cogan, T. and Corry, J. (2012): Prevalence, antibiotic resistance and RAPD typing of Campylobacter species isolated from ducks, their rearing and processing environments in Penang, Malaysia. Int. J. Food Microbiol., 154: 197-205.

Bolton, D.J. (2015): Review: Campylobacter and survival factors. Food Microbiol, 48: 99-108.

Camarda, A.; Newell, D.G.; Nasti, R. and Di Modugnoa, G. (2000): Genotyping Campylobacter jejuni strains isolated from the gut and oviduct of laying hens. Avian Dis., 44: 907-912.

Clark, A.G. and Bueschkens, D.H. (1986): Survival and growth of Campylobacter jejuni in egg yolk and albumen. J. Food Protect., 49, 135-141.

Coker, K.O.; Isokpehi, R.D.; Bolaji, N; Thomas, B.N.; Amisu, K.O. and Obit, C.L. (2002): Human Campylobacteriosis in Developing Countries 1. Emerg. Infect. Dis., 8: 237- 243.

Doyle, M.P. (1984): Association of Campylobacter jejuni with laying hens and eggs. Appl Environ Microb., 47: 533- 536.

Espina, L.; Monfort, S.; Álvarez, I.; Garćia-Gonzalo, D. and Pagán; R. (2014): Combination of pulsed electric fields, mild heat and essential oils as an alternative to the ultrapasteurization of liquid whole egg. Int. J. Food Microbiol., 189:119-125.

European Food Safety Authority (EFSA) (2005): Scientific report of the Scientific Panel on Biological Hazards on the request from the Commission related to Campylobacter in animals and food stuffs. Annex to the EFSA J., 173: 1-105.

European Food Safety Authority (EFSA) (2010): The community summary report on trends and sources of zoonoses, zoonotic agents and foodborne outbreaks in the European Union in 2008. EFSA J., 8:1496
European Food Safety Authority (EFSA) (2011): Panel on Biological Hazards (BIOHAZ); scientific opinion on Campylobacter in broiler meat production: control options and performance objectives and/or targets at different stages of the food chain. EFSA J., 9: 141. 10.2903/j.efsa. 2011. 2105

European Food Safety Authority (EFSA) (2014): EFSA explains zoonotic diseases. Available at http://www.efsa.europa.eu/en/corporate/doc/ fact sheet campylobacter. pdf. Accessed 8 August 2016.

European Food Safety Authority (EFSA) (2015): EU summary report on trends and sources of zoonoses, zoonotic agents and food-borne outbreaks in 2013. EFSA J. 13, 3991 10.2903/ j.efsa.2015.3991

Fonseca, B.B.; Beletti, M.F.; Torres de Melo, R.; Mendonça, E. P.; Coelho, L.R.; Nalevaiko, P.C. and Rossi, D.A. (2014): Campylobacter jejuni in commercial eggs. Braz. J. of Microbiol., 45: 76-79.

Ganan, M.; Silvan, J.M.; Carrascosa, A.V. and Martinez-Rodriguez, A.J. (2012): Review, Alternative strategies to use antibiotics or chemical products for controlling Campylobacter in the food chain. Food Control, 24, 6-14.

Hussein, A.A. and El-Prince, E. (2002): Campylobacter jejuni and coli in commercial eggs sold in Assiiut Governorate, Egypt. $11^{\text {th }}$ European Poultry Conference 6-10 Sept. Bremen, Germany.

Jacobs-Reitsma W.F. (1997): Aspects of epidemiology of Campylobacter in poultry. Vet. Quart., 19: 113-117.

Jonaidi-Jafari, N.; Khamesipour, F.; Ranjbar, R. and Kheiri, R. (2016): Prevalence and antimicrobial resistance of Campylobacter species isolated from the avian eggs. Food Control, 70: 35-40.

Josefsen, M.; Bhunia, A.K.; Engvall, E.O.; Fachmann, M.S.R. and Hoofar, J. (2015): Monitoring Campylobacter in the poultry production chain-From culture to genes and beyond. J. Microbiol. Meth., 112: 118-125.

Maruyama, S. and Katsube, Y. (1990): Isolation of Campylobacter jejuni from the eggs and organs in experimentally infected laying Japanese quails (Coturnix coturnix japonica). Jpn. J. Vet. Sci., 52: 671-674.

Maruyama, S.; Morita, Y. and Katsube, Y. (1995): Invasion and viability of Campylobacter jejuni in experimentally contaminated Japanese quails eggs. J. Vet. Med. Sci., 57, 587-590.

Messelhäusser, U.; Thärigen, D.; Elmer-Englhard, D.; Bauer, H.; Schreiner, H. and Höller, C. (2011): Occurrence of Thermotolerant Campylobacter spp. on Eggshells: a Missing 
Link for Food-Borne Infections? Appl. Environ. Microbiol., 77: 3896-3897.

Mohammed, F.A. (2016): Prevalence of Campylobacter in table eggs sold in Sohag City. M.V.Sc. Thesis Fac. of Vet. Med. Assiut Univ.

Moyle, T.; Drake, K.; Gole, V.; Chousalkar, K. and Hazel, S. (2016): Bacterial contamination of eggs and behaviour of poultry flocks in the free range environment. Comp. Immunol. Microbiol. Infect. Dis., http://dx.doi.org/10. 1016/j.cimid.2016.10.005

Musgrove, M.T.; Jones, D.R.; Northcutt, J.K.; Cox, N.A. and Harrison, M.A. (2005): Shell Rinse and Shell Crush Methods for the Recovery of Aerobic Microorganisms and Enterobacteriaceae from Shell Eggs. J. Food Protect, 68: 2144-2148.

Neill, S.D.; Campbell, J.N. and O'Brien, J.J. (1985): Egg penetration by Campylobacter jejuni. Avian Pathol., 14, 313-320.

Park, S.F. (2002): The physiology of Campylobacter species and its relevance to their role as foodborne pathogens. Int. J. Food Microbiol., 74, 177-188.

Robyn, J.; Rasschaert, G.; Pasmans, F. and Heyndrickx, M. (2015): Thermotolerant Campylobacter during broiler rearing: risk factors and intervention. Compr. Rev. Food Sci. F., 14:81-105

Sahin, O.; Morishita, T.Y. and Zhang, Q. (2002): Campylobacter colonization in poultry: sources of infection and modes of transmission. Anim. Health Res. Rev., 3: 95105.

Sahin, O.P.; Kobalka, P. and Zhang, Q. (2003): Detection and survival of Campylobacter in chicken eggs. J. App. Microbiol., 95: 10701079.

Shane S.M.; Gifford, D.H. and Yogasundram, K. (1986): Campylobacter jejuni contamination of eggs. Vet. Res. Commun., 10: 487-492.

Vandamme, P.; Vancanneyt, M.; Pot, B.; Mels, L.; Hoste, B.; Dewettinck, D.; Vlaes, L.; Van Den Borre, C.; Higgins, R. and Hommez, J. (1992): Polyphasic taxonomic study of the emended genus Arcobacter with Arcobacter butzleri comb. nov. and Arcobacterskirrowii sp. nov., an aerotolerant bacterium isolated from veterinary specimens. Int. J. Syst. Bacteriol., 42: 344-56.

Waldenström, J.; Broman, T.; Carlsson, I.; Hasselquist, D.; Achterberg, R.P.; Wagenaar, J.A. and Olsen, B. (2002): Prevalence of Campylobacter jejuni, Campylobacter lari, and Campylobacter coli in Different Ecological Guilds and Taxa of Migrating Birds. Appl. Environ. Microbiol., 68: 59115917.

Wang, G.; Clark, C.G.; Taylor, T.M.; Pucknell, C.; Barton, C.; Price, L.; Woodward, D.L. and Rodgers, F.G. (2002): Colony Multiplex PCR Assay for Identification and Differentiation of Campylobacter jejuni, C. coli, C. lari, C. upsaliensis, and C. fetus subsp. Fetus. J. Clin. Microbiol., 40: 4744-4747.

Wei, B.; Cha, S.Y.; Yoon, R.H.; Kang, M.; Roh, J.H.; Seo, H.S.; Lee, J.A. and Jang, H.K. (2016): Prevalence and antimicrobial resistance of Campylobacter spp. isolated from retail chicken and duck meat in South Korea. Food Control, 62: 63-68.

مدى تواجد ميكروبات الكامبيلوباكتر المتحملة للحرارة فى بيض المائدة

Email: moon_zam@outlook.sa Assiut University web-site: www.aun.edu.eg

ان ميكروب الكامبيلوباكتر وخاصة الكامبيلو باكتر جيجوناي وكامبيلوباكتر كولاي من احد اهم الميكروبات المسببة للاسهال. الهدف

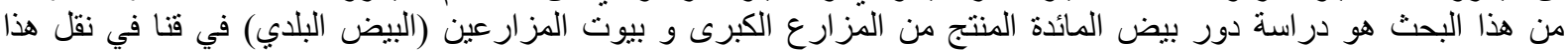

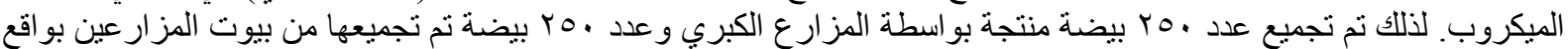

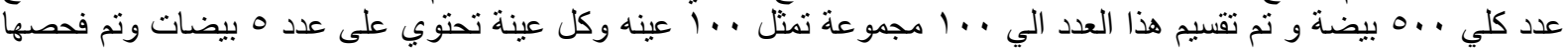

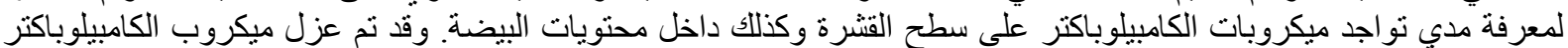

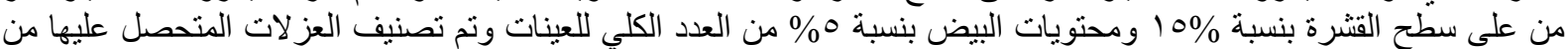

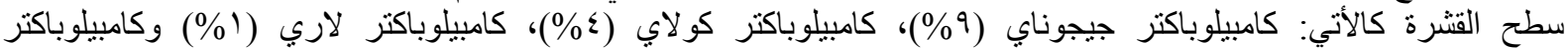

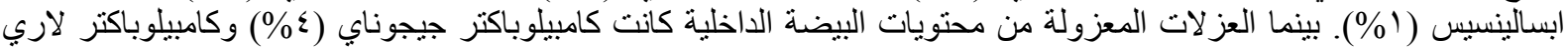

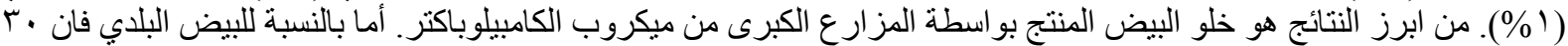

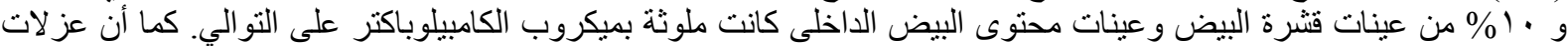
الكامبيلوباكتر جيجوناي و الكامبيلوباكتر كو لاي تم التاكد منها باستخدام تفاعل البلمرة المتسلسل المتعدد. 